\title{
Mapping Research Waste Filter Cigarette Butts As A Substitute For Coarse Aggregate In Concrete By The Method Of Systematic Literature ReVIEW
}

\section{Pemetaan Riset Limbah Filter Puntung Rokok Sebagal Pengganti Agregat Kasar Beton Dengan Metode Systematic Literature Review}

\author{
Thofan Agung Wibowo ${ }^{1}$, Anisah², M. Agphin Ramadhan ${ }^{3}$ \\ ${ }^{123}$ Program Studi Pendidikan Teknik Bangunan, Universitas Negeri Jakarta \\ Gedung L Kampus A Universitas Negeri Jakarta, Jalan Rawamangun (13220), \\ Telp. (62-21) 4890046
}

e-mail: thopanlampard@gmail.com, anisah75.awi@gmail.com, agphin@unj.ac.id

\begin{abstract}
This study aims to determine the mapping of research related to cigarette butts filter waste as coarse aggregate for making concrete according to its category. This study uses systematic literature review techniques to conduct research by analyzing the literature. Literature collection is done by searching several digital libraries by entering a search string that has been made based on the research queation with publication limits between 2011-2020. The results showed that from 182 literature obtained 4 of them were suitable for analysis. Based on the 4 literatures, it is known that normal concrete and lightweight concrete are produced from cigarette butts filter waste. The concrete that is most often made is normal concrete and the best compressive strength value that can be produced is $29.6 \mathrm{MPa}$ with a cigarette butt filter waste mixture of $0.1 \%$ of the concrete density. The best quality produced is medium quality with $K 300.84$ and is included in the category of structural concrete.
\end{abstract}

Keywords: research mapping, waste, cigarette butts filters, concrete, systematic literature review

\section{PENDAHULUAN}

Pada era modern saat ini berbagai bidang kehidupan mengalami perubahan yang semakin maju dan membuat aktivitas manusia lebih mudah dan cepat. Seperti halnya di bidang konstruksi bangunan, yang semakin inovatif dalam perkembangan bahan-bahan bangunan, terutama beton. Beton pada dasarnya tercipta dari proses percampuran semen, agregat dan air (Candra dkk, 2019). Sifat beton yaitu padat dan memiliki sifat kedap terhadap air yang mempengaruhi berat jenis beton itu sendiri. Menurut SNI 03-2847-2002, beton bagi menjadi 3 golongan berdasarkan berat satuan yaitu, beton ringan dengan berat satuan $<1.900 \mathrm{~kg} / \mathrm{m}^{3}$, beton normal dengan berat satuan $2.200 \mathrm{~kg} / \mathrm{m}^{3}-2.500 \mathrm{~kg} / \mathrm{m}^{3}$, dan beton berat dengan berat satuan $>2.500 \mathrm{~kg} / \mathrm{m}^{3}$.

Setiap perkembangan teknologi pasti memiliki hal positif maupun negatif, dalam teknologi pembuatan beton memilik dampak positif, yaitu beton lebih kuat dan lebih ringan sesuai dengan berat jenis dan fungsinya. Tidak hanya memiliki sisi positif, beton juga memiliki sisi negatif seperti kerusakan alam yang semakin masif karena bahan dari penyusun beton itu sendiri. Agregat yang umum digunakan sebagai material penyusun beton berasal dari sumber daya alam yang terus menerus dieksploitasi, sehingga menyebabkan kerusakan lingkungan yang semakin meningkat. Data yang di miliki Bappeda DKI Jakarta tahun 2004, limbah padat yang dihasil oleh DKI Jakarta mencapai 10.220 ton/hari. Limbah padat itu terdiri dari limbah industri, perumahan, dan pertanian termaksud limbah padat yang berasal dari aktivitas pembangunan konstruksi. Limbah konstruksi ialah material yang sudah tidak dimanfaatkan lagi yang di peroleh dari kegiatan konstruksi (Franklin, 1998). 
Menurut Asroni (2010), beton dibuat dengan cara mengeras campuran semen, air, agregat halus (pasir) dan agregat kasar (batu pecah). Terkadang campuran bahan lain (admixture) ditambahkan untuk memperbaikinya kualitas beton. Menurut Mulyono (2004), tujuan penggunaan agregat sebagai bahan penyusun beton karena memilik fungsi sebagai penghasil kekuatan pada beton, mengurangi susut pengerasan beton dan beton akan memiliki gradari yang baik. Metode untuk mengurangi penggunaan sumber daya alam sebagai material penyusun beton dengan cara pemanfaatan limbah yang tidak terpakai untuk di jadikan alternatif material yang digunakan. Salah satu limbah yang dapat di manfaatkan adalah limbah filter puntung rokok. Limbah filter puntung rokok dipilih sebagai material penyusun beton karena limbah ini banyak terbuang tanpa dimanfaatkan kembali. Mengingat perokok aktif Indonesia merupakan yang terbesar di ASEAN yang menyumbang 34\% dari total penduduk Indonesia pada tahun 2018 (SEATCA, 2018). Banyaknya jumlah perokok di Indonesia menunjukkan banyaknya limbah filter rokok yang dihasilkan. Dengan adanya pengelolahan limbah puntung rokok ini diharapkan akan mengurangi limbah puntung rokok yang dihasilkan oleh konsumen rokok. Filter puntung rokok juga memiliki berat jenis yang sangat ringan yang membuat beton akan mengurangi berat jenis beton itu sendiri (Candra dkk, 2019). Kandungan dalam filter putung rokok terdapat Nikotin (C10H14N2) yang bergunakan sebagai antikorosi (Olin, 2019) dan terdapat juga kandungan n80 yang memiliki manfaat untuk memproteksi baja dari karat sehingga sesuai sebagai bahan tambahan pembuatan beton (Jun Zhao, 2010).

Penelitian terkait dengan penggunaan limbah filter puntung rokok sebagai material bahan bangunan telah banyak dilakukan. Dengan jenis beton yang dihasilkan dengan formulasi terbaik yang didapatkan. Banyaknya macam-macam beton yang dibuat dengan menggunakan limbah filter puntung rokok, diperlukan adanya pemetaan riset yang mengenai pengolahan limbah filter puntung rokok menjadi material pembuatan beton. Selain pemetaan jenis beton, perlu juga dilakukan pengelompokan campuran dan mutu beton terbaik, yang digunakan secara maksimal dalam produksi beton dengan limbah filter puntung rokok. Oleh karena itu perlu dilakukan klasifikasi pemanfaatan limbah filter puntung rokok sebagai agregat untuk pembuatan beton agar lebih mudah dalam mendapatkan metode terbaik yang hasil akhirnya berupa laporan data statistik yang ditulis dalam bentuk diagram. Dalam penelitian ini, literatur digunakan sebagai data. Literatur dapat diunduh dari berbagai digital library yang tersedia seperti Google Scholar, EBSCO, Sciendirect, Elsiver, dan Researchgate.

Berdasarkan permasalahan yang ada, penelitian ini akan melakukan penelitian yaitu pemetaan riset limbah filter puntung rokok sebagai pengganti agregat dalam pembuatan beton. Metode literature review yang digunakan dalam penelitian ini adalah metode systematic literature review. Systematic literature review dipilih karena metode ini banyak digunakan dan merupakan metode penelitian terbaik dalam studi sejenis. Penelitian ini juga menggunakan literatur yang diterbitkan dalam 10 tahun terakhir sebagai bahan penelitian pemetaan limbah filter puntung rokok sebagai pengganti agregat dalam pembuatan beton.

\section{METODELOGI PENELITIAN}

Metode yang digunakan dalam penelitian adalah dengan menggunakan metode systematic literature review. Metode systematic literature review dilakukan dengan melakukan literature dari berbagai penelitian relevan yang telah di publikasi sebelumnya dengan menggunakan tahapan planning, conducting, dan reporting.

Semua literatur yang berkaitan dengan filter rokok dijadikan sebagai sumber data penelitian yang dipilih. Literatur yang dipilih untuk penelitian harus sesuai dengan kriteria yang telah ditentukan. Data yang digunakan dalam rentang waktu 2011-2020, diperoleh melalui situs Google Scholar, EBSCO, Sciendirect, Elsiver, Researchgate. Data yang digunakan hanya berhubungan dengan limbah filter puntung rokok sebagai agregat beton.

Dalam mencapai tujuan penelitian, terdapat 6 rumusan masalsah. Rumusan masalah ini membantu untuk mengumpulkan semuainformasi yang dibutuhkan dalam menganalisa:

- (RQ1) Apa macam-macam beton yang menggunakan campuran limbah filter puntung rokok sebagai agregat kasar?

- (RQ2) Berapa campuran yang baik dari limbah filter puntung rokok dalam pembuatan beton?

- (RQ3) Berapa mutu beton yang dihasilkan dari limbah filter puntung rokok?

- (RQ4) Apa tipe beton untuk struktur dengan menggunakan limbah filter puntung rokok? 
Teknik pengumpulan data menggunakan laman dari digital library yang sudah disebutkan seperti Google Scholar, EBSCO, Sciendirect, Elsiver, dan Researchgate dalam pencarian makalah terkait. Format data yang di dapat berupa .pdf yang di dapat dari kegiatan pengunduhan dalam digital library di atas.

Pada pencarian yang dilakukan harus sesuai dengan aturan yang sudah dibuat sebelumnya dengan tahun penerbitan yang sudah di buat dan bahasa artikel yang dicari. Demikian juga dengan search string yang telah dibuat dengan berdasarkan RQ (research question) yang sudah ditentukan yang bersifat konsisten dengan menggunakan digital library yang digunakan.

Search string yang akan digunakan: (cigarette butts filter waste OR Cigarette filter) AND (concrete OR lightweight concrete OR normal concrete OR heavy concrete OR mass concrete OR ferro-cement OR fiber concrete).

Untuk menentukan dokumen literatur yang akan di analisis datanya dalam penelitian yang akan dilakukan harus sesuai dengan kriteria yaitu kriteria inklusi dan ekslusi. Kriteria ini meliputi: literatur yang dibatasi penerbitannya dari tahun 2011-2020, menggunakan Bahasa inggris dalam penulisannya, literatur yang membahas tentang ringkasan limbah filter puntung rokok. Sedangkan untuk kriteria ekslusi meliputi: literatur yang dibatasi penerbitannya sebelum tahun 2011 dan setelah 2020, tidak menggunakan Bahasa inggris dalam penulisannya, literatur yang tidak membahas tentang ringkasan limbah filter puntung rokok.

Literatur yang didapat berdasarkan dengan kriteria yang sudah ditentukan diatas tersebut kemudian dilakukan dengan mengindentifikasikan terhadap literatur yang dipakai dan selanjutnya dengan memproses data ekstraksi yang hasilnya akan memenuhi dari RQ (research question) yang telah dibuat sebelumnya.

\section{PEMBAHASAN}

Dari 4 literatur yang telah di analisis, diperoleh 2 jenis beton yang menggunakan limbah filter puntung rokok, 2 jenis beton itu adalah beton normal dan beton ringan. Dari 2 jenis beton tersebut di peroleh dari campuran kandungan limbah filter puntung rokok, beton normal menggunakan campuran limbah filter puntung rokok dengan jumlah kandungan $0 \%-0,83 \%$ dari berat jenis beton, sedang kan beton ringan menggunakan campuran limbah filter puntung rokok dengan jumlah kandungan rata-rata 10,3\% dari berat jenis beton yang dibuat. Dari literatur itu di peroleh mutu beton dari campuran limbah filter puntung rokok, beton normal didapat nilai kuat tekan beton optimum adalah $38 \mathrm{MPa}$, sedang kan beton ringan didapat nilai kuat tekan sebersar 9,85 MPa. Dari 4 literatur yang telah di analisis juga, diperoleh 2 mutu beton yang berbeda menggunakan limbah filter puntung rokok, 2 mutu beton itu adalah mutu sedang dengan dengan $20-35 \mathrm{MPa}$ dan K250 - K400 masuk dalam kategori beton struktural dan mutu rendah dengan < $20 \mathrm{MPa}$ dan K-BO (Nol) masuk dalam kategori beton non struktural.

\section{HASIL PENELITIAN}

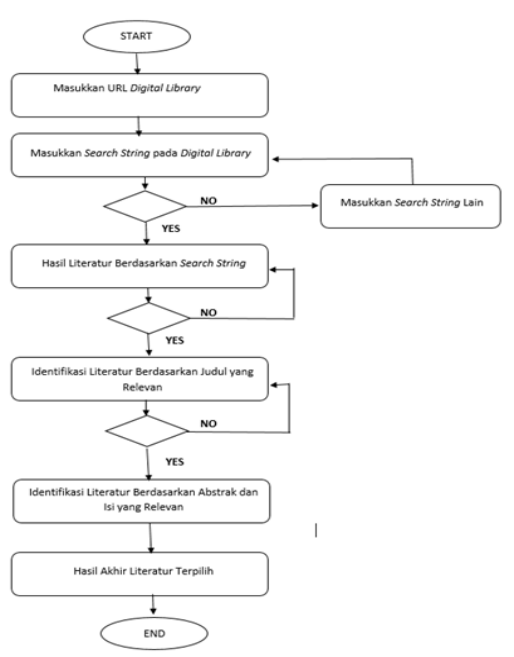

Gambar 1. Diagram Alir Penelitian 
Gambar tersebut menunjukkan proses pencarian untuk 39 literatur yang dipilih. Identifikasi atau pencarian dilakukan pada digital library yang telah ditentukan yaitu Google Scholar, EBSCO, Sciendirect, Elsiver, Researchgate,dan IEEE eXplore dengan menggunakan Search string yang telah dirancang sebelumnya. Search string yang digunakan di setiap digital library konsisten seperti yang dibuat sebelumnya, yaitu (cigarette butts filter waste OR Cigarette filter) AND (concrete OR lightweight concrete OR normal concrete OR heavy concrete OR mass concrete OR ferro-cement OR fiber concrete). Saat melakukan pencarian di digital library, ditemukan 182 literatur Inggris yang cocok dengan pencarian ini.

Dari 182 literatur yang ditemukan menurut hasil pencarian, literatur tersebut diseleksi kembali sesuai dengan judul penelitian yang relevan, yaitu limbah filter puntung rokok sebagai agregat kasar beton didapatkan 15 literatur yang terkait dengan 15 literatur tersebut, Tidak semua memiliki muatan atau pembahasan terkait dengan muatan yang akan diteliti, sehingga perlu dilakukan pengkajian kualitas dari 15 litaretur tersebut.

Literatur yang terkait dengan judul kemudian ditinjau dan dianalisis berdasarkan abstrak dan isi literatur. Dari 15 literatur yang direview dan dianalisis berdasarkan abstrak, ditemukan literatur yang sesuai dengan topik yang diteliti, sebanyak 4 literatur yang tercantum sesuai isinya. dari 4 literatur tersebut semuanya berasal dari jurnal internasional.

\section{RQ1: Macam- Macam Beton}

Rumusan masalah RQ1 mengenai tentang macam-macam beton yang menggunakan campuran limbah filter puntung rokok. Tabel 1 menunjukan pengelompokan macam-macam beton.

Dari Tabel 1 terlihat bawah beton normal merupakan kategori macam-macam beton tertinggi dalam penelitian. Hal ini menunjukan kebanyakan peneltian saat ini lebih tertarik di beton normal dibanding beton yang lain. Selanjutnya, beton ringan menjadi macam beton lainnya yang digunakan dalam 1 literatur. Kesimpulan dari RQ1 menunjukan bahwa penelitian yang banyak diminati untuk studi kasus beton yang menggunakan campuran limbah filter puntung rokok pada 10 tahun terakhir adalah beton normal.

Tabel 1.Kategori Macam-Macam Beton

\begin{tabular}{|l|l|l|c|}
\hline \multicolumn{1}{|c|}{ Kategori } & \multicolumn{1}{|c|}{ Definisi } & \multicolumn{1}{|c|}{ Paper Penelitian } & Jumlah \\
\hline Beton Normal & $\begin{array}{l}\text { beton yang memiliki berat isi } \\
\text { berkisar (2200-2500) kg/m3. Beton } \\
\text { yang di hasilkan dalam ketiga } \\
\text { literatur ini }\end{array}$ & $\begin{array}{l}\text { (Luo, dkk., 2019), } \\
\text { (Shruti, dkk., 2018), } \\
\text { (Richardson, Alan. } \\
2012)\end{array}$ & 3 \\
\hline Beton Ringan & $\begin{array}{l}\text { Berat jenisnya tak lebih dari 1900 } \\
\text { kg/m3. }\end{array}$ & (Agata, dkk., 2019) & 1 \\
\hline
\end{tabular}

Sumber: Data Olahan (2021)

\section{RQ2: Campuran Pembuatan Beton}

Rumusan masalah RQ2 mengenai tentang campuran pembuatan beton yang menggunakan campuran limbah filter puntung rokok. Tabel 2 menunjukan pengelompokan campuran pembuatan beton.

Dalam hasil ekstraksi ditemukan bahwa dari 4 literatur memiliki perbedaan dalam menggunakan campuran limbah filter puntung rokok pembuatan beton. Pada literatur pertama dengan penulis Luo, dkk. (2019) menggunakan campuran beton dengan kandungan 0\%,0,21\%,0,313\%, 0,417\%,0,52\%, 0,63\%,dan 0,83\%. Pada literatur kedua dengan penulis Agata, dkk. (2019) menggunakan campuran beton dengan kandungan 10,3\%. Pada literatur ketiga dengan penulis Shruti, dkk. (2018) menggunakan campuran beton dengan kandungan $0 \%, 0,1 \%$, dan 0,25\%. Pada literatur ke empat dengan penulis Richardson, Alan (2012) menggunakan campuran beton dengan kandungan 0,13\% dan 0,11\%. Hasil penelitian dari RQ2 ini menunjukan bahwa tidak ada ketentuan khusus dalam menentukan besarnya kandungan limbah filter puntung rokok dalam pembuatan beton. 
Tabel 2. Kategori Campuran Beton

\begin{tabular}{|c|c|c|c|}
\hline Kategori & Definisi & Paper Penelitian & Jumlah \\
\hline $\begin{array}{l}0 \%, 0,21 \%, \\
0,313 \%, \\
0,417 \%, \\
0,52 \%, 0,63 \%, \\
0,83 \%\end{array}$ & $\begin{array}{l}\text { Ukuran cetakan berbentuk kotak berukuran } 10 \\
\mathrm{~cm} \text { x } 10 \mathrm{~cm} \text { x } 10 \mathrm{~cm} \text {, dengan jumah sampel } 21 \\
\text { dengan masing masing campuran } 3 \text { sampel. }\end{array}$ & (Luo, dkk., 2019), & 1 \\
\hline $10,3 \%$ & $\begin{array}{l}\text { Ukuran cetakan berbentuk kotak berukuran } 15 \\
\mathrm{~cm} \times 15 \mathrm{~cm} \times 15 \mathrm{~cm} \text {, dengan jumah sampel } 5\end{array}$ & (Agata, dkk,, 2019) & 1 \\
\hline $\begin{array}{l}0 \%, 0,1 \% \\
0,25 \%\end{array}$ & Ketebalan balok $60 \mathrm{~mm}$ sampai $50 \mathrm{~mm}$ & (Shruti, dkk., 2018) & 1 \\
\hline $0,13 \%, 0,11 \%$ & $\begin{array}{l}\text { Ukuran cetakan berbentuk kotak berukuran } 15 \\
\mathrm{~cm} \times 15 \mathrm{~cm} \times 15 \mathrm{~cm} \text {, dengan jumah sampel } 4 \\
\text { dan Ukuran cetakan berbentuk balok } \\
\text { berukuran } 15 \mathrm{~cm} \times 10 \mathrm{~cm} \times 10 \mathrm{~cm} \text {, dengan } \\
\text { jumah sampel } 2\end{array}$ & $\begin{array}{l}\text { (Richardson, Alan. } \\
\text { 2012) }\end{array}$ & 1 \\
\hline
\end{tabular}

Sumber: Data Olahan (2021)

\section{RQ3: Mutu Beton}

Rumusan masalah RQ3 mengenai tentang mutu beton yang dihasilkan oleh campuran limbah filter puntung rokok. Tabel 3 menunjukan pengelompokan mutu beton.

Dalam hasil ekstraksi ditemukan bahwa dari 4 literatur memiliki perbedaan dalam mutu beton dari campuran limbah filter puntung rokok pada pembuatan beton. Pada literatur pertama dengan penulis Luo, dkk. (2019) mendapatkan nilai kuat tekan tertinggi 29,27MPa dengan kandungan 0,21\%. Pada literatur kedua dengan penulis Agata, dkk. (2019) mendapatkan nilai kuat tekan 9,85 MPa dengan kandungan 10,3 \%. Pada literatur ketiga dengan penulis Shruti, dkk. (2018) mendapatkan nilai kuat tekan tertinggi 29,6MPa dengan kandungan 0,1\%. Pada literatur ke empat dengan penulis Richardson, Alan (2012) mendapatkan nilai kuat tekan $38 \mathrm{MPa}$ dengan kandungan 0,13\%. Hasil penelitian dari RQ3 ini menunjukan bahwa hasil pengujian kuat tekan beton dengan mengganti agregat kasar dengan limbah puntung rokok setelah beton 28 hari memiliki rata-rata yang berbeda, untuk nilai kuat tekan beton dengan campuran limbah puntung rokok fillter tertinggi adalah $38 \mathrm{MPa}$ dengan 0,13\% kandungan limbah filter puntung rokok.

Tabel 3. Kategori Mutu Beton

\begin{tabular}{|c|c|c|c|}
\hline Kategori & Definisi & Paper Penelitian & Jumlah \\
\hline $\begin{array}{l}29,27 \mathrm{MPa}, \\
27,47 \mathrm{MPa}, \\
26,8 \mathrm{MPa} \\
24,67 \mathrm{MPa} \text {, } \\
22,03 \mathrm{MPa} \text {, } \\
21,47 \mathrm{MPa}\end{array}$ & $\begin{array}{l}\text { Hasil pengujian kuat tekan beton dengan } \\
\text { mengganti agregat kasar dengan limbah } \\
\text { puntung rokok setelah beton } 28 \text { hari } \\
\text { memiliki rata-rata yang berbeda, untuk } \\
\text { nilai kuat tekan beton dengan campuran } \\
\text { limbah puntung rokok fillter tertinggi } \\
\text { adalah } 29,27 \mathrm{MPa} \text { dengan } 0,21 \% \\
\text { kandungan limbah filter puntung rokok. }\end{array}$ & (Luo, dkk., 2019), & 1 \\
\hline 9,85 MPa & $\begin{array}{l}\text { Hasil pengujian kuat tekan beton dengan } \\
\text { penggantian agregat kasar dengan } \\
\text { limbah puntung rokok fillter pada umur } \\
\text { beton } 28 \text { hari memiliki rata-rata yang } \\
\text { berbeda, untuk nilai kuat tekan beton } \\
\text { dengan campuran agregat kasar limbah }\end{array}$ & (Agata, dkk., 2019) & 1 \\
\hline
\end{tabular}




\begin{tabular}{|c|c|c|c|}
\hline & $\begin{array}{l}\text { puntung rokok hanya mencapai } 9,85 \\
\text { MPa dengan kandungan } 10,3 \% \text { limbah } \\
\text { filter puntung rokok. }\end{array}$ & & \\
\hline $\begin{array}{l}\text { 29,6MPa, } \\
26,6 \mathrm{MPa},\end{array}$ & $\begin{array}{l}\text { Hasil pengujian kuat tekan beton dengan } \\
\text { mengganti agregat kasar dengan limbah } \\
\text { puntung rokok setelah beton } 28 \text { hari } \\
\text { memiliki rata-rata yang berbeda, untuk } \\
\text { nilai kuat tekan beton dengan campuran } \\
\text { limbah puntung rokok fillter tertinggi } \\
\text { adalah } 29,6 \mathrm{MPa} \text { dengan } 0,1 \% \\
\text { kandungan limbah filter puntung rokok. }\end{array}$ & (Shruti, dkk., 2018) & 1 \\
\hline $38 \mathrm{MPa}$ & $\begin{array}{l}\text { Hasil pengujian kuat tekan beton dengan } \\
\text { penggantian agregat kasar dengan } \\
\text { limbah puntung rokok fillter pada umur } \\
\text { beton } 28 \text { hari memiliki rata-rata untuk } \\
\text { nilai kuat tekan beton dengan campuran } \\
\text { agregat kasar limbah puntung rokok } \\
\text { hanya mencapai } 38 \mathrm{MPa} \text { dengan } \\
\text { kandungan } 0,13 \% \text { limbah filter puntung } \\
\text { rokok. }\end{array}$ & $\begin{array}{l}\text { (Richardson, Alan. } \\
\text { 2012) }\end{array}$ & 1 \\
\hline
\end{tabular}

Sumber: Data Olahan (2021)

\section{RQ4: Tipe Beton Struktur}

Rumusan masalah RQ4 mengenai tentang tipe beton struktur yang menggunakan campuran limbah filter puntung rokok. Tabel 4 menunjukan pengelompokan macam-macam beton.

Dari Tabel 4 terlihat bawah beton struktural merupakan kategori tipe beton struktur tertinggi dalam penelitian. Hal ini menunjukan kebanyakan peneltian saat ini lebih tertarik di tipe beton struktur dibanding beton non struktural. Selanjutnya, beton non struktural menjadi tipe beton struktur yang digunakan dalam 1 literatur. Kesimpulan dari RQ4 menunjukan bahwa penelitian yang banyak diminati untuk studi kasus beton yang menggunakan campuran limbah filter puntung rokok pada 10 tahun terakhir adalah tentang beton struktural.

Tabel 4. Kategori Tipe Beton Struktur

\begin{tabular}{|c|c|c|c|}
\hline Kategori & Definisi & Paper Penelitian & Jumlah \\
\hline $\begin{array}{l}\text { Beton struktural } \\
\text { dengan mutu beton } \\
\text { sedang } \\
20 \text { - } 40 \mathrm{MPa} \text { dan K250 - } \\
\mathrm{K} 400\end{array}$ & $\begin{array}{l}\text { Beton struktural adalah jenis beton } \\
\text { yang mengandung komponen besi } \\
\text { cor dalam suatu campuran } \\
\text { pengecoran, beton struktural juga } \\
\text { termasuk pekerjaan besi dan } \\
\text { pengecoran beton. Sedangkan } \\
\text { pekerjaan lain yang sering dikaitkan } \\
\text { dengan pekerjaan beton adalah } \\
\text { pekerjaan persiapan struktur baja, } \\
\text { pekerjaan penutupan beton, } \\
\text { pekerjaan finishing beton, pekerjaan } \\
\text { pondasi beton, pekerjaan pasangan }\end{array}$ & $\begin{array}{l}\text { (Luo, dkk., 2019), (Shruti, } \\
\text { dkk., 2018), (Richardson, } \\
\text { Alan. 2012) }\end{array}$ & 3 \\
\hline
\end{tabular}




\begin{tabular}{|l|l|l|l|}
\hline & bata dan lain sebagainya. & & \\
\hline $\begin{array}{l}\text { Beton non struktural } \\
\text { dengan mutu beton } \\
\text { rendah <20 MPa dan K- } \\
\text { B0 (Nol) }\end{array}$ & $\begin{array}{l}\text { Beton non struktural merupakan } \\
\text { pekerjaan pengecoran beton yang } \\
\text { tidak secara langsung mengandung } \\
\text { elemen struktur, termasuk besi } \\
\text { sebagai bahan penguat beton cor. }\end{array}$ & & \\
& & & \\
\hline
\end{tabular}

Sumber: Data Olahan (2021)

\section{PENUTUP}

KESIMPULAN

Dari hasil yang diperoleh dalam penelitian dapat disimpulkan bahwa dengan membuat peta penelitian dalam literatur yang membahas limbah filter puntung rokok sebagai agregat kasar dalam pembuatan beton menggunakan metode systematic literature review maka dapat dilihat hasil dari penelitian tersebut pada Gambar 4.2. Peta riset penelitian yang dihasilkan menunjukkan bahwa:

1. Dari 4 litaretur yang di analisis diperoleh 2 macam beton yang dibuat dengan menggunakan limbah filter puntung rokok yaitu beton normal dan beton ringan.

2. Beton normal menjadi beton yang paling banyak di gunakan dalam literatur yang di analisis. Selanjutnya beton ringan yang hanya 1 literatur yang menggunakan limbah filter puntung rokok.

3. Dari ke 4 literatur diperoleh nilai kuat tekan dengan campuran agregat kasar limbah filter puntung rokok yaitu hanya mencapai nilai tertinggi sebesar $38 \mathrm{MPa}$ dengan campuran 0,13\%. Mutu yang didapat adalah mutu sedang dengan maksimal $\mathrm{K} 387,492$ dengan tipe beton struktural dan mutu rendah dengan $\mathrm{K}$ B0 dengan tipe beton non struktural.

\section{SARAN}

Masukan yang penulis berikan kepada siapapun yang akan melakukan penelitian adalah penelitian pemetaan limbah filter puntung rokok sebagai agregat kasar pembuatan beton sebaiknya:

1. Digital library yang digunakan untuk mendapatkan literatur tidak hanya dibatasi dengan Google Scholar, EBSCO, Sciendirect, Elsiver,dan Researchgate sehingga dokumen yang didapat bisa semakin beragam.

2. Research question dapat ditambah untuk memperluas hasil pemetaan dan akan menghasilkan lebaih banyak pengetahuan mengenai pemanfaatan limbah filter puntung rokok sebagai agregat kasar sebagai pembuatan beton.

\section{DAFTAR PUSTAKA}

[1] Cahyadi, Wahyu D. 2012. Studi Kuat Tekan Beton Normal Mutu Rendah yang Mengandung Abu Sekam Padi (RHA) dan Limbah Adukan Beton (CSW). Laporan Akhir: Universitas Indonesia.

[2] Candra, et al. 2019. Pemanfaatan Limbah Puntung Rokok Filter Sebagai Bahan Campuran Beton Ringan. UkaRsT. 3 (1):76-85.

[3] Citation: Richardson, Alan (2012) Cigarette filter material and polypropylene fibres in concrete to control drying shrinkage. In: 8th International Conference: Concrete in the Low Carbon Era, 9-11 July 2012, Dundee, Scotland.

[4] Lian, T., \& Dorotheo, U. (2018). The Tobacco Contrl Atlas ASEAN Region. Bangkok: Southeast Asia Tobacco Control Alliance (SEATCA).

[5] Luo, T., Zhang, Z., Zhang, J., Sun, C., \& Yanjun, J. (2019). Experimental Study on Uniaxial Compressive Strength of Concrete Incorporated with Cigarette Butts. IOP Conference Series: Earth and Environmental Science, 233, 052030. 
[6] Wahono, Romi Satria. 2015. A Systematic Literature Review of Software Defect Prediction: Research Trends, Datasets, Methods and Frameworks. Journal of Software Engineering 1 (1): 1-16. https://doi.org/2356-3974

[6] Mohajerani A, Kadir A A, Larobina L. 2016. A practical proposal for solving the world's cigarette butt problem: Recycling in fired clay bricks. Waste Management, 52:228-244

[7] Mohajerani A, Tanriverdi Y, Bao T N, et al. 2017. Physico-mechanical properties of asphalt concrete incorporated with encapsulated cigarette butts[J].

[8] Muhammad Waqar Ashraf.2012. Levels of Heavy Metals in Popular Cigarette Brands and Exposure to These Metals via Smoking. The Scientific World Journal, Article ID 729430

[9] Badan Standarisasi Nasional. (2002). SNI 03-2847-2002. Tata cara perhitungan struktur beton untuk bangunan gedung. Jakarta: Badan Standarisasi Nasional. 